\title{
AKTIVITAS ANTIOKSIDAN KOMBINASI EKSTRAK ETANOL LIDAH BUAYA (Aloe vera L.) dan GANGGANG HIJAU (Ulva lactuca L.)
}

\author{
Azizah Nada Septiawan ${ }^{1}$, Emelda ${ }^{2 *}$, Saddam Husein ${ }^{3}$ \\ ${ }^{1}$ Program Studi Sarjana Farmasi; Fakultas IImu-IImu Kesehatan; Universitas Alma Ata \\ ${ }^{2}$ Program Studi Sarjana Farmasi; Fakultas IImu-Ilmu Kesehatan; Universitas Alma Ata \\ ${ }^{3}$ Program Studi Farmasi, Sekolah Tinggi Ilmu Kesehatan Adila, Bandar Lampung \\ Email: dinda.ayupratiwi2806@gmail.com, emelda@almaata.ac.id, \\ saddamhusein0701@gmail.com \\ Korespondensi: \\ Emelda \\ Program Studi Sarjana Farmasi; Fakultas IImu-IImu Kesehatan; Universitas Alma Ata \\ emelda@almaata.ac.id
}

\begin{abstract}
Abstrak
Penelitian yang dilakukan Rahman menyatakan bahwa ekstrak lidah buaya (Aloe vera L.) memiliki aktivitas antioksidan dengan adanya perubahan warnaungu pekat menjadi kuning. Sedangkan Penelitian yang dilakukan oleh Emelda menjelaskan bahwa kemampuan menangkap radikal bebas ekstrak etanol ganggang hijau (Ulva lactuca L.) lebih baik dibandingkan Vitamin $\mathrm{C}$ dilihat dari nilai $\mathrm{IC}_{50}$ dan semakin tinggi konsentrasi ekstrak etanol ganggang hijau maka semakin tinggi kemampuan menangkap radikal bebas. Kombinasi dari dua jenis atau lebih tumbuhan yang memiliki kandungan antioksidan diharapkan dapat menghasilkan daya antioksidan yang lebih tinggi karena sifatnya sinergis. Penelitian ini bertujuan untuk mengetahui aktivitas antioksidan pada kombinasi ekstrak etanol lidah buaya (Aloe vera L.) dan ganggang hijau (Ulva lactuca L.) melalui nilai $\mathrm{IC}_{50}$ pada kombinasi ekstrak etanol lidah buaya (Aloe vera L.) dan ganggang hijau (Ulva lactuca L.). Jenis penelitian ini adalah eksperimental untuk mengetahui aktivitas antioksidan pada ekstrak tunggal dan kombinasi ekstrak lidah buaya (Aloe vera $\mathrm{L}$.) dan ganggang hijau (Ulva lactuca $\mathrm{L}$.) dengan perbandingan 1:1; 1:2 dan 2:1 dengan menggunakan metode DPPH. Hasil Pengujian aktivitas antioksidan dengan metode DPPH menunjukkan bahwa kontrol positif, ekstrak etanol lidah buaya tunggal, ganggang hijau tunggal berserta kombinasi dengan perbandingan 1:1; 1:2 dan 2:1 memiliki aktivitas antioksidan kuat sampai sangat kuat. Kesimpulan dari penelitian ini adalah kombinasi ekstrak etanol lidah buaya dan ganggang hijau 1:2 memiliki aktivitas antioksidan tertinggi dengan nilai $\mathrm{IC}_{50}$ sebesar $16,51 \mu \mathrm{g} / \mathrm{ml}$.
\end{abstract}

Kata Kunci: aloe vera; antioksidan; DPPH; Ulva lactuca $\mathbf{L}$.

\section{ANTIOXIDANT ACTIVITY COMBINED ETHANOL EXTRACT OF ALOE VERA (Aloe vera L.) and GREEN ALGAE (Ulva lactuca L.)}

\begin{abstract}
Research conducted by Rahman stated that the extract of aloe vera (Aloe vera L.) has antioxidant activity with a change in color from dark purple to yellow. Meanwhile, research conducted by Emelda explained that the ability to scavenge free radicals of ethanolic green algae extract (Ulva lactuca L.) was better than Vitamin C seen from the IC50 value and the higher the concentration of ethanolic extract of green algae, the higher the ability
\end{abstract}


to scavenge free radicals. The combination of two or more types of plants that contain antioxidants is expected to produce higher antioxidant power because of its synergistic nature. This research aims to determine the antioxidant activity of the combination of aloe vera (Aloe vera $L$.) ethanol extract and green algae (Ulva lactuca $L$.) and the $I C_{50}$ value in the combination of aloe vera (Aloe vera L.) ethanol extract and green algae (Ulva lactuca L.) extract. This type of research is experimental to determine the antioxidant activity of single and combined extracts of aloe vera (Aloe vera $L$.) and green algae (Ulva lactuca L.) with a ratio of 1:1; 1:2 and 2:1 using the DPPH method. The results of the antioxidant activity test using the DPPH method showed that the positive control, ethanol extract of single aloe vera, single green algae and their combination 1:1; 1:2; $2: 1$ had strong to very strong antioxidant activity. The combination of ethanol extract of aloe vera and green algae 1:2 has the highest antioxidant potential with an $I C_{50}$ value of $16.51 \mu \mathrm{g} / \mathrm{mI}$.

Keywords: aloe vera; antioxidants; DPPH; Ulva lactuca L.

\section{PENDAHULUAN}

Radikal bebas adalah atom atau molekul yang mempunyai satu atau lebih elektron tetapi tidak mempunyai pasangan, agar mempunyai pasangan radikal bebas akan berikatan dengan elektron yang ada di sekitar dengan cara menyerang dan berikatan dengan elektron yang ada disekitar. Senyawa yang diserang akan rusak jika telah berikatan dengan radikal bebas. Kerusakan sel atau jaringan yang diakibatkan radikal bebas dapat menyebabkan penyakit degeneratif seperti penyakit kanker, auto imun dan peradangan. Tubuh manusia secara alami dapat menghasilkan antioksidan tetapi bila jumlah radikal bebas melebihi jumlah antioksidan dalam tubuh radikal bebas akan menyerang protein ataupun DNA dan pada kondisi ini tubuh membutuhkan antioksidan dari luar ${ }^{1}$.

Penelitian yang dilakukan Rahman menyatakan bahwa ekstrak lidah buaya (Aloe vera L.) memiliki aktivitas antioksidan dengan adanya perubahan warnaungu pekat menjadi kuning. Nilai IC I0 $_{50}$ dari ekstrak lidah buaya sebesar 250,42 ppm yang berdasarkan klasifikasi Blois tergolong antioksidan lemah². Daging lidah buaya juga bersifat sebagai anti kanker dan anti inflamasi ${ }^{3}$. Penelitian yang dilakukan oleh Emelda menjelaskan bahwa kemampuan menangkap radikal bebas ekstrak etanol ganggang hijau (Ulva lactuca L.) lebih baik dibandingkan Vitamin $\mathrm{C}$ dilihat dari nilai $\mathrm{IC}_{50}$ dan semakin tinggi konsentrasi ekstrak etanol ganggang hijau maka semakin tinggi kemampuan menangkap radikal bebas ${ }^{4}$. Ganggang hijau memiliki senyawa bioaktif diantaranya yaitu alkaloid, polisakarida, glikosida, steroid, terpenoid tanin dan fenol sebagai antioksidan. Ganggang hijau juga mengandung mineral, protein, lipid, hemiselulosa, malondialdehid, selulosa, lignin dan serat tinggi ${ }^{5,6}$.

Penelitian antioksidan dengan mengkombinasikan tanaman-tanaman telah dilakukan 
untuk meningkatkan aktivitas antioksidan seperti daun sirsak dan daun jambu biji rimpang temu giring dan daun pugun tanoh ${ }^{8}$. Kombinasi dari dua jenis atau lebih tumbuhan yang memiliki kandungan antioksidan diharapkan dapat menghasilkan daya antioksidan yang lebih tinggi karena sifatnya sinergis. Penelitian ini bertujuan untuk mengetahui aktivitas antioksidan pada kombinasi ekstrak etanol lidah buaya (Aloe vera L.) dan ganggang hijau (Ulva lactuca L.) dan nilai IC ${ }_{50}$ pada kombinasi ekstrak etanol lidah buaya (Aloe vera L.) dan ganggang hijau (Ulva lactuca L.).

\section{METODE PENELITIAN}

\section{Alat dan Bahan}

Alat yang digunakan adalah toples maserasi, cawan porselin, water bath, blender, alumunium foil, kuvet, batang pengaduk, cawan porselen (pyrex), kain flanel, neraca analitik, kertas saring, flakon, alat gelas (pyrex), spektrofotometer UV-Vis merk ThermoFisher dengan nomer seri 5A4V 291110.

Bahan yang digunakan adalah daging daun lidah buaya yang berasal dari Tamantirto Yogyakarta, ganggang hijau yang berasal dari Pantai Sepanjang Gunung Kidul, akuades, etanol 96\% dan metanol yang diproduksi oleh PT.Brataco, serbuk DPPH (Merck), asam galat produksi (Merck), pereaksi meyer (Merck), pereaksi dragendorff (Merck), Asam Klorida ( $\mathrm{HCl}$ ) (Merck), serbuk Magnesium (Mg) (Merck), Besi (I) Klorida (FeCl) (Merck), Asam Asetat Glasial $\left(\mathrm{CH}_{3} \mathrm{COOH}\right)$ (Merck) dan Asam Sulfat $\left(\mathrm{H}_{2} \mathrm{SO}_{4}\right)$ (Merck).

\section{Rancangan Penelitian}

Jenis penelitian ini adalah eksperimental untuk mengetahui aktivitas antioksidan pada ekstrak tunggal dan kombinasi ekstrak lidah buaya (Aloe vera L.) dan ganggang hijau (Ulva lactuca L.) 1:1; 1:2 dan 2:1 dengan menggunakan metode DPPH.

\section{Determinasi}

Determinasi daun lidah buaya (Aloe vera L.) dan ganggang hijau (Ulva lactuca L.) dilakukan di Laboratorium Biologi Fakultas SAINS dan Teknologi Terapan Universitas Ahmad Dahlan. Determinasi dilakukan untuk mengurangi kemungkinan kesalahan identitas sampel.

\section{Pengumpulan Bahan dan Penyiapan Simplisia}

Sampel yang akan diteliti adalah daging daun lidah buaya (Aloe vera L.) dan ganggang hijau (Ulva lactuca L.). 
1. Preparasi sampel daun lidah buaya (Aloe vera L.)

Daun lidah buaya dibersihkan, dikupas kulitnya, lalu dipotong kecil-kecil dan dihaluskan menggunakan blender hingga seperti jus, kemudian dihitung volumenya menggunakan gelas ukur.

2. Preparasi sampel ganggang hijau (Ulva lactuca L.)

Ganggang hijau yang sudah dikumpulkan dicuci dengan air mengalir, setelah itu dikeringkan, kemudian dihaluskan menggunakan blender dan diayak menggunakan ayakan 30 mesh.

\section{Pembuatan Ekstrak}

1. Daging daun lidah buaya (Aloe vera L.)

Pembuatan ekstrak daging daun lidah buaya (Aloe vera L.) menggunakan metode maserasi atau perendaman. Daging daun lidah buaya sebanyak $500 \mathrm{gr}$ di maserasi dengan pelarut etanol $96 \%$ sebanyak $1 \mathrm{~L}$ selama 24 jam dan remaserasi 1 kali, kemudian hasil maserat disaring menggunakan kertas saring dan didapatkan filtrat. Filtrat kemudian dipanaskan menggunakan water bath untuk memisahkan pelarut etanol 96\% dengan ekstrak kental daging daun lidah buaya dan dihitung rendemen².

2. Ganggang hijau (Ulva lactuca L.)

Pembuatan ekstrak ganggang hijau (Ulva lactuca L.) menggunakan metode maserasi atau perendaman. Serbuk ditimbang sebanyak $500 \mathrm{gr}$ di maserasi dengan pelarut etanol $96 \%$ sebanyak $1 \mathrm{~L}$ selama 24 jam dan remaserasi 2 kali. Maserat disaring menggunakan kain flanel, kemudian maserat dipanaskan menggunakan water bath untuk memisahkan pelarut etanol $96 \%$ dengan ekstrak kental dan dihitung rendemen².

\section{Uji Pendahuluan}

1. Uji pendahuluan menggunakan metode DPPH Larutan ganggang hijau dan lidah buaya masing-masing dipipet sebanyak $1 \mathrm{~mL}$ dan ditambahkan $1 \mathrm{~mL}$ larutan DPPH 0,15 Mm9.

2. Skrining Fitokimia Identifikasi kandungan kimia pada ekstrak daging daun lidah buaya dan ganggang hijau terhadap senyawa alkaloid, flavonoid, saponin, tanin, steroid dan triterpenoid ${ }^{9}$. 


\section{Uji Kuantitatif}

1. Pembuatan Larutan DPPH

Serbuk DPPH ditimbang sebanyak 19,7 mg dan dilarutkan dalam metanol sampai 100 $\mathrm{mL}(0,5 \mathrm{mM})^{10}$.

2. Pembuatan Larutan Induk Lidah Buaya dan ganggang hijau $(100 \mu \mathrm{g} / \mathrm{mL})$

Ekstrak kental daging lidah buaya ditimbang $5 \mathrm{mg}$ dilarutkan dalam metanol sebanyak $50 \mathrm{ml}$ (konsentrasi $100 \mu \mathrm{g} / \mathrm{mL})^{10}$.

3. Pembuatan Larutan Kontrol Positif

Serbuk asam galat ditimbang sebanyak $10 \mathrm{mg}$ dan dilarutkan dalam metanol sampai $100 \mathrm{ml}(100 \mu \mathrm{g} / \mathrm{mL})^{10}$.

4. Pengukuran Aktivitas Antioksidan

a. Ll ekstrak masing-masing dipipet sebanyak $1 \mathrm{~mL}, 2 \mathrm{~mL}, 3 \mathrm{~mL}, 4 \mathrm{~mL}$ dan $5 \mathrm{~mL}$ untuk mendapatkan konsentrasi larutan uji $4 \mu \mathrm{g} / \mathrm{mL}, 8 \mu \mathrm{g} / \mathrm{mL}, 12 \mu \mathrm{g} / \mathrm{mL}, 16 \mu \mathrm{g} / \mathrm{mL}$ dan $20 \mathrm{\mu g} / \mathrm{mL}$ untuk larutan uji ekstrak etanol tunggal lidah buaya dan ganggang hijau ${ }^{10}$.

b. Ll ekstrak masing-masing dipipet sebanyak $0,5 \mathrm{~mL} ; 1,0 \mathrm{~mL} ; 1,5 \mathrm{~mL} ; 2,0 \mathrm{~mL}$ dan 2,5 $\mathrm{mL}$ untuk mendapatkan konsentrasi larutan uji $4 \mu \mathrm{g} / \mathrm{mL}, 8 \mu \mathrm{g} / \mathrm{mL}, 12 \mu \mathrm{g} / \mathrm{mL}, 16$ $\mu \mathrm{g} / \mathrm{mL}$ dan $20 \mu \mathrm{g} / \mathrm{mL}$ untuk larutan uji kombinasi ekstrak dengan perbandingan $1: 1^{10}$.

c. Ll ekstrak dipipet masing-masing 0,25:0,75 mL; 0,5:1,5 mL; 0,75:2,25 mL; 1,25:3,0 $\mathrm{mL}$ dan 1,25:3,75 mL untuk mendapatkan konsentrasi campuran larutan uji 4 Mg/ $\mathrm{mL}, 8 \mu \mathrm{g} / \mathrm{mL}, 12 \mu \mathrm{g} / \mathrm{mL}, 16 \mu \mathrm{g} / \mathrm{mL}$ dan $20 \mu \mathrm{g} / \mathrm{mL}$ untuk larutan uji kombinasi ekstrak dengan perbandingan $1: 2^{10}$.

d. Ll ekstrak dipipet masing-masing 0,75:0,25 mL; 1,5:0,5 mL; 2,25:0,75 mL; 3,0:1,0 mL dan 3,75:1,25 mL untuk mendapatkan konsentrasi campuran larutan uji 4 $\mu \mathrm{g} / \mathrm{mL}$, $8 \mu \mathrm{g} / \mathrm{mL}, 12 \mu \mathrm{g} / \mathrm{mL}, 16 \mu \mathrm{g} / \mathrm{mL}$ dan $20 \mu \mathrm{g} / \mathrm{mL}$ untuk larutan uji kombinasi ekstrak dengan perbandingan 2:1 $1^{10}$.

e. Ll asam galat dipipet sebanyak $0,35 \mathrm{~mL} ; 0,45 \mathrm{~mL} ; 0,55 \mathrm{~mL} ; 0,65$ dan $0,75 \mathrm{~mL}$ untuk mendapatkan konsentrasi larutan uji 1,4 $\mu \mathrm{g} / \mathrm{mL}, 1,8 \mu \mathrm{g} / \mathrm{mL}, 2,2 \mu \mathrm{g} / \mathrm{mL}, 2,6 \mu \mathrm{g} / \mathrm{mL}$ dan $3 \mu \mathrm{g} / \mathrm{mL}^{10}$.

Kemudian ditambahkan $1 \mathrm{~mL}$ larutan DPPH 0,5 mM ke dalam masing-masing labu ukur, lalu volumenya dicukupkan dengan metanol sampai garis tanda. Pengukuran dilakukan setelah didiamkan selama 35 menit pada panjang gelombang $517 \mathrm{~nm}$, setelah didapatkan 
absorbansi, dihitung persen inhibisi masing-masing larutan (Gambar 1).

$$
\% \text { Inhibisi }=\frac{A_{\text {Blanko }}-A_{\text {Sampel }}}{A_{\text {Blanko }}} \times 100 \%
$$

Gambar 1. Rumus Perhitungan Persentase (\%) Inhibisi

Keterangan :

$A_{\text {Blanko }}=$ Absorbansi tidak mengandung sampel

$A_{\text {sampel }}=$ Absorbansi mengandung sampel

\section{Hasil dan Pembahasan}

Penelitian yang dilakukan menggunakan tanaman lidah buaya dan ganggang hijau. Lidah buaya diperoleh dari Tamantirto dan gangang hijau diperoleh dari Pantai Sepanjang, Gunung Kidul, Yogyakarta. Determinasi yang telah dilakukan terdapat angka dan kode untuk kunci determinasi yang menunjukkan bahwa semua ciri-ciri dari bentuk anatomi tanaman tersebut adalah lidah buaya dan ganggang hijau secara makroskopik dan mikroskopik, maka dapat dipastikan bahwa tanaman yang digunakan dalam penelitian ini adalah benar merupakan lidah buaya dan ganggang hijau dengan nama ilmiah Aloe vera L. dan Ulva lactuca L dapat dilihat pada Gambar 2.

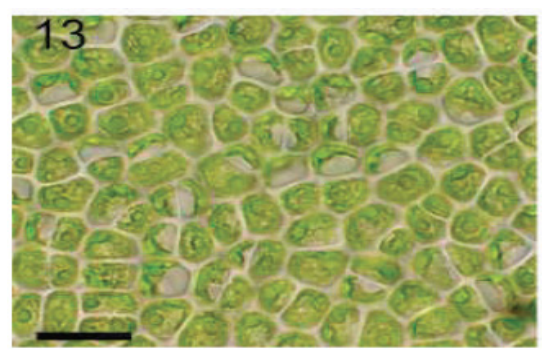

(a)

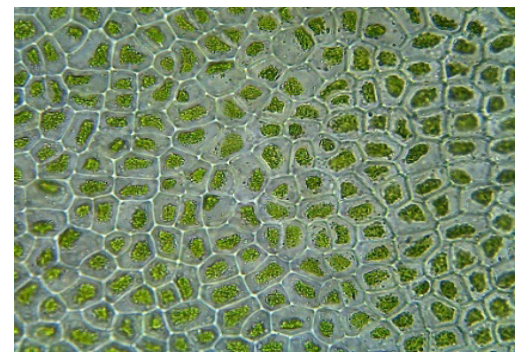

(b)

Gambar 2. Hasil Mikroskopik Ganggang Hijau (a) secara Teoritis (b) Determinasi Ganggang Hijau

Daging daun lidah buaya diperoleh dari daun yang sudah dikupas sebanyak $1,1 \mathrm{~kg}$ dan dihaluskan dan serbuk ganggang hijau sebanyak 500 gr. Ekstrak dibuat dari daging daun lidah buaya dan serbuk ganggang hijau yang sudah dihaluskan dengan cara dingin yaitu dengan metode maserasi. Tujuan dihaluskan adalah agar kontak permukaan serbuk dan pelarut lebih besar sehingga senyawa kimia yang terdapat pada ganggang hijau dapat terekstrak dengan mudah. Metode maserasi yang bertujuan untuk memisahakan senyawa aktif yang terdapat pada bahan (lidah buaya dan ganggang hijau) menggunakan pelarut etanol $96 \%$ sebanyak $3 \mathrm{~L}$ untuk menghindari terjadinya penguraian senyawa karena adanya panas ${ }^{11}$. Pelarut etanol 96\% memiliki konsentrasi lebih tinggi akan masuk ke dalam inti sel lidah buaya dan ganggang 
hijau melewati dinding sel dan membran sel akan pecah, metabolit sekunder akan keluar dan terlarut dalam etanol $96 \%{ }^{12}$. Pelarut etanol bersifat polar yang dapat menarik senyawasenyawa polar seperti alkaloid, flavonoid, tannin, saponin, kuartener, komponen fenolik, asam amino dan senyawa polar lainnya ${ }^{13}$.

Ekstraksi dilakukan pengulangan sebanyak 2 kali. Penyaringan dilakukan menggunakan kain flanel sehingga didapatkan residu dan filtrat. Filtrat hasil penyaringan dipekatkan dengan waterbath dan penangas air untuk memisahkan pelarut etanol $96 \%$ dari ekstrak kental. Hasil rendemen dari suatu sampel diperlukan untuk mengetahui banyaknya ekstrak yang diperoleh selama proses ekstraksi dan hasil rendemen ada hubungannya dengan senyawa aktif dari suatu sampel sehingga apabila jumlah rendemen semakin banyak maka jumlah senyawa aktif yang terkandung dalam sampel juga semakin banyak ${ }^{14}$. Menurut Harbone tingginya senyawa aktif yang terdapat pada suatu sampel ditunjukkan dengan tingginya jumlah rendemen ${ }^{13}$. Nilai rendemen yang dihasilkan dapat disebabkan dari beberapa faktor seperti ukuran partikel dari sampel, metode maserasi, lama waktu ekstraksi, perbandingan dari sampel dan pelarut, jenis pelarut, kondisi dan waktu penyimpanan ${ }^{14}$. Ekstrak kental lidah buaya menghasilkan rendemen 1,20\% berbentuk semisolid berupa ekstrak kental berwarna coklat kekuningan, lengket, berbau khas lidah buaya (Aloe vera L.) dan ekstrak kental ganggang hijau (Ulva lactuca L.) menghasilkan rendemen 8,012\% berbentuk semisolid berupa ekstrak kental berwarna hitam kehijauan, lengket dan berbau khas ganggang hijau. Hasil rendemen lidah buaya dan ganggang hijau termasuk rendah karena pengaruh waktu antara pelarut dan bahan dan penguapan yang terlalu lama. Etanol sebagai pelarut tidak mengekstraksi seluruh komponen metabolit sekunder pada lidah buaya dan ganggang hijau.

Uji pendahuluan bertujuan untuk mendeteksi senyawa yang terkandung dalam tanaman berdasarkan golongannya. Hasil uji pendahuluan dengan metode DPPH pada Tabel 1 menunjukkan bahwa ekstrak kental lidah buaya (Aloe vera L.) dan ekstrak kental ganggang hijau (Ulva lactuca L.) pada Tabel 2 memiliki aktivitas antioksidan karena terjadi perubahan warna dari ungu menjadi kuning karena pada senyawa DPPH terdapat elektron yang tidak berpasangan. Perubahan intensitas warna ungu terjadi karena adanya peredaman radikal bebas yang dihasilkan oleh molekul DPPH dengan atom hidrogen yang dilepaskan oleh molekul senyawa sampel sehingga terbentuk senyawa difenil pikril hidrazin dan menyebabkan terjadinya perubahan warna DPPH dari ungu menjadi kuning ${ }^{15}$. 
Azizah Nada Septiawan, Emelda, Saddam Husein

Aktivitas Antioksidan Kombinasi Ekstrak Etanol Lidah Buaya (Aloe Vera L.) dan

Ganggang Hijau (Ulva Lactuca L.)

Tabel I. Hasil Uji Pendahuluan Ekstrak Lidah Buaya

\begin{tabular}{lcl}
\hline $\begin{array}{c}\text { Pengujian Ekstrak } \\
\text { Lidah Buaya }\end{array}$ & Hasil & \multicolumn{1}{c}{ Keterangan } \\
\hline Metode DPPH & + & $\begin{array}{l}\text { Terbentuk warna kuning } \\
\text { Alkaloid }\end{array}$ \\
Flavonoid & + & $\begin{array}{l}\text { Terbentuk endapan merah (Dragendorf) } \\
\text { Serbentuk endapan jingga (Mayer) }\end{array}$ \\
Tanin & + & Perubahan warna menjadi jingga \\
Steroid & + & Terbentuk busa setinggi 1cm yang stabil \\
Triterpenoid & + & Terbentuk larutan berwarna hitam \\
\hline
\end{tabular}

Tabel II. Hasil Uji Pendahuluan Ekstrak Ganggang Hijau

\begin{tabular}{|c|c|c|}
\hline $\begin{array}{c}\text { Pengujian Ekstrak } \\
\text { Ganggang Hijau }\end{array}$ & Hasil & Keterangan \\
\hline Metode DPPH & + & Terbentuk warna kuning \\
\hline Alkaloid & + & $\begin{array}{l}\text { Terbentuk endapan merah (Dragendorf) } \\
\text { Terbentuk endapan jingga (Mayer) }\end{array}$ \\
\hline Flavonoid & + & Perubahan warna menjadi jingga \\
\hline Saponin & - & Tidak terbentuk busa setinggi $1 \mathrm{~cm}$ yang stabil \\
\hline Tanin & - & $\begin{array}{l}\text { Tidak terbentuk larutan berwarna biru tua atau } \\
\text { hitam }\end{array}$ \\
\hline Steroid & + & Terbentuk warna kebiruan \\
\hline Triterpenoid & - & Tidak terbentuk warna merah/ungu \\
\hline
\end{tabular}

Berdasarkan uji skrining fitokimia dapat diketahui bahwa ekstrak lidah buaya (Aloe vera $\mathrm{L}$.) mengandung senyawa aktif yang sama, hal ini sesuai dengan penelitian sebelumnya mengandung alkaloid, flavonoid, saponin, tanin dan steroid ${ }^{16}$. Berdasarkan uji skrining fitokimia dapat diketahui bahwa ekstrak etanol ganggang hijau (Ulva lactuca L.) mengandung senyawa aktif yang sama, hal ini sesuai dengan penelitian sebelumnya mengandung alkaloid, flavonoid dan steroid ${ }^{17}$.

Pengujian aktivitas antioksidan secara kuantitatif dilakukan dengan metode DPPH. Kelemahan DPPH adalah sangat sensitif terhadap cahaya karena mudah terdegradasi. Berdasarkan penelitian, serapan maksimum DPPH berada pada panjang gelombang $517 \mathrm{~nm}$. Panjang gelombang maksimum DPPH antara $515-522 \mathrm{~nm}^{15}$. Senyawa DPPH adalah senyawa yang memiliki gugus kromofor, mengadung nitrogen yang tidak stabil dan berwarna ungu. Senyawa yang berwarna dapat diukur pada panjang gelombang 400-800 nm menggunakan spektrofotomer UV-Vis ${ }^{13,15}$. 
Hasil ekstraksi selanjutnya dibuat larutan induk, larutan seri konsentrasi dan larutan pembanding, setelah itu diinkubasi dan diukur absorbansinya dengan menggunakan spektrofotometer UV-Vis pada panjang gelombang $517 \mathrm{~nm}$, setelah itu dievaluasi efek antioksidannya dengan dicari persen inhibisi masing-masing konsentrasi ${ }^{17}$. Data persen inhibisi dibuat grafik antara konsentrasi larutan $(x)$ dan persen inhibisi $(y)$ yang akan mendapatkan persamaan regresi linear.

Ekstrak lidah buaya dan ganggang hijau memiliki aktivitas antioksidan karena mengandung senyawa fenol seperti flavonoid yang terdapat pada ekstrak kental. Senyawa fenolik yaitu senyawa dengan gugus $\mathrm{OH}$ yang terikat langsung pada gugus cincin hidrokarbon aromatik. Senyawa fenolik mempunyai kemampuan untuk menyumbangkan atom hidrogen, sehingga radikal bebas DPPH dapat tereduksi menjadi bentuk yang lebih stabil, semakin banyak gugus hidroksil yang dimiliki senyawa fenolik, maka semakin besar aktivitas antioksidan yang diperoleh dan warna akan berubah menjadi kuning ${ }^{18,19}$. Perubahan warna mengakibatkan perubahan absorbansi pada panjang gelombang maksimum DPPH menggunakan spektrofotometri UV-Vis sehingga akan diketahui nilai aktivitas peredaman radikal bebas yang dinyatakan dengan nilai Inhibition Concentration $50 \%{ }^{15}$.

Aktivitas antioksidan menggunakan metode DPPH dinyatakan dengan Inhibition Concentration $50 \%\left(\mathrm{IC}_{50}\right)$ yaitu konsentrasi ekstrak yang mampu dihambat aktivitas DPPH sebesar $50 \%$ dan semakin kecil nilai $\mathrm{IC}_{50}$ maka semakin tinggi aktivitas antioksidan ${ }^{20}$. Nilai $\mathrm{IC}_{50}$ didapatkan menggunakan persamaan regresi linear. Larutan yang mendapatkan perlakuan yang sama dengan larutan sampel tetapi tidak mengandung analat disebut blanko. Pengukuran absorbansi blanko bertujuan untuk melihat besarnya serapan dari zat bukan analat ${ }^{19}$. Hasil pengukuran blanko diperoleh absorbansi sebesar 0,812 .

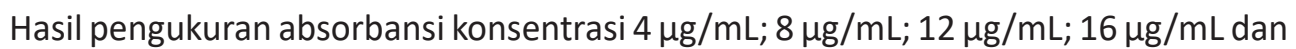
$20 \mu \mathrm{g} / \mathrm{mL}$ pada Tabel 3. secara keseluruhan menunjukkan bahwa semakin tinggi konsentrasi ekstrak, semakin rendah absorbansi yang diperoleh, absorbansi semakin rendah maka semakin tinggi persen inhibisi dan semakin tinggi persen inhibisi maka semakin rendah nilai $\mathrm{IC}_{50}$ dan semakin tinggi kandungan antioksidan pada ekstrak lidah buaya dan ganggang hijau beserta kombinasinya.

Hasil analisis peredaman radikal bebas oleh ekstrak tunggal lidah buaya dan ganggang hijau berserta kombinasi menunjukkan bahwa kenaikan konsentrasi berbanding lurus dengan peningkatan persen perendaman karena semakin banyak atom hidrogen dari ekstrak etanol lidah buaya dan ganggang hijau yang berpasangan dengan elektron radikal bebas sehingga 
Azizah Nada Septiawan, Emelda, Saddam Husein

Aktivitas Antioksidan Kombinasi Ekstrak Etanol Lidah Buaya (Aloe Vera L.) dan

Ganggang Hijau (Ulva Lactuca L.)

serapan semakin menurun yang ditandai dengan berubahnya warna larutan menjadi kuning dan juga akan menurunkan absorbansinya ${ }^{8}$.

Hasil pada Tabel 3. menunjukkan bahwa ekstrak etanol tunggal dan kombinasi lidah buaya dan ganggang hijau serta asam galat sebagai kontrol positif memiliki aktivitas yang berbeda satu sama lain. Perbedaan nilai $\mathrm{IC}_{50}$ pada masing-masing ekstrak tunggal maupun kombinasi disebabkan oleh adanya distribusi jumlah atau jenis golongan senyawa metabolit sekunder yang bersifat antioksidan berdasarkan kepolaran pelarut yang digunakan ${ }^{21}$.

Hasil nilai IC $\mathrm{C}_{50}$ ekstrak tunggal lidah buaya sebesar $64,81 \mu \mathrm{g} / \mathrm{mL}$ yang berdasarkan klasifikasi Blois termasuk kategori antioksidan kuat karena pada rentang 50-100 $\mu \mathrm{g} / \mathrm{mL}$. Penelitian lain yang dilakukan dengan metode yang sama lidah buaya memiliki aktivitas antioksidan kuat dengan konsentrasi yang lebih tinggi ${ }^{22}$. Ekstrak ganggang hijau memiliki nilai $\mathrm{IC}_{50}$ sebesar $21,34 \mu \mathrm{g} / \mathrm{mL}$ yang berdasarkan klasifikasi Blois termasuk kategori antioksidan sangat kuat. Penelitian yang dilakukan menggunakan konsetrasi yang lebih kecil dibandingkan penelitian sebelumnya dan didapatkan hasil aktivitas antioksidan sangat kuat juga ${ }^{23}$. Nilai $\mathrm{IC}_{50}$ asam galat diperoleh sebesar $2,76 \mu \mathrm{g} / \mathrm{mL}$. Aktivitas antioksidan tunggal lidah buaya dan ganggang hijau lebih rendah dibandingkan asam galat.

Tabel III. Hasil Uji Aktivitas Antioksidan Asam Galat, Ekstrak Tunggal dan Kombinasi Lidah Buaya dan Ganggang Hijau

\begin{tabular}{cccc}
\hline Sampel & Konsentrasi $(\mu \mathrm{g} / \mathrm{ml})$ & $\%$ Inhibisi & IC50 \\
\hline Ekstrak Lidah Buaya & $4 \mu \mathrm{g} / \mathrm{ml}$ & 35,22 & $64,77 \mu \mathrm{g} / \mathrm{mL}$ \\
$8 \mu \mathrm{g} / \mathrm{ml}$ & 36,45 & \\
Ekstrak Ganggang Hijau & $12 \mu \mathrm{g} / \mathrm{ml}$ & 36,70 & \\
& $16 \mu \mathrm{g} / \mathrm{ml}$ & 38,30 & \\
& $20 \mu \mathrm{g} / \mathrm{ml}$ & 39,16 & \multirow{2}{*}{$21,34 \mu \mathrm{g} / \mathrm{mL}$} \\
& $4 \mu \mathrm{g} / \mathrm{ml}$ & 4,43 & \\
Ekstrak Kombinasi 1:1 & $8 \mu \mathrm{g} / \mathrm{ml}$ & 13,67 & \\
& $12 \mu \mathrm{g} / \mathrm{ml}$ & 24,14 & \\
& $16 \mu \mathrm{g} / \mathrm{ml}$ & 36,33 & \\
& $20 \mu \mathrm{g} / \mathrm{ml}$ & 46,55 & \\
& $4 \mu \mathrm{g} / \mathrm{ml}$ & 3,20 & \\
& $8 \mu \mathrm{g} / \mathrm{ml}$ & 11,82 & \\
& $12 \mu \mathrm{g} / \mathrm{ml}$ & 22,29 &
\end{tabular}




$\begin{array}{cccc} & 4 \mu \mathrm{g} / \mathrm{ml} & 20,69 & 16,51 \mu \mathrm{g} / \mathrm{mL} \\ 8 \mu \mathrm{g} / \mathrm{ml} & 29,06 & \\ 12 \mu \mathrm{g} / \mathrm{ml} & 41,38 & \\ 16 \mu \mathrm{g} / \mathrm{ml} & 48,89 & \\ 20 \mu \mathrm{g} / \mathrm{ml} & 57,39 & \\ & 4 \mu \mathrm{g} / \mathrm{ml} & -9,98 & 17,44 \mu \mathrm{g} / \mathrm{mL} \\ & 8 \mu \mathrm{g} / \mathrm{ml} & 22,17 & \\ 12 \mu \mathrm{g} / \mathrm{ml} & 33,99 & \\ & 16 \mu \mathrm{g} / \mathrm{ml} & 44,33 & \\ 20 \mu \mathrm{g} / \mathrm{ml} & 55,42 & \\ \text { Asam Galat Kombinasi } 1: 2 & 37,56 & 2,76 \mu \mathrm{g} / \mathrm{mL} \\ & 1,4 \mu \mathrm{g} / \mathrm{ml} & 45,57 & \\ & 1,8 \mu \mathrm{g} / \mathrm{ml} & 48,03 & \\ 2,2 \mu \mathrm{g} / \mathrm{ml} & 48,52 & \\ 2,6 \mu \mathrm{g} / \mathrm{ml} & 50,25 & \\ & 3 \mu \mathrm{g} / \mathrm{ml} & & \\ & & & \end{array}$

Rendahnya aktivitas antioksidan bisa disebabkan oleh beberapa faktor, yaitu karena metode maserasi yang digunakan belum menarik sepenuhnya komponen kimia yang bersifat antioksidan dalam lidah buaya dan ganggang hijau. Asam galat adalah senyawa murni dan ekstrak lidah buaya dan ganggang hijau merupakan senyawa campuran yang banyak mempunyai senyawa metabolit sekunder yang dapat mempengaruhi aktivitas antioksidan ${ }^{19}$. Kombinasi ekstrak etanol lidah buaya dan ganggang hijau 1:2 pada pengujian kombinasi ekstrak memiliki potensi antioksidan tertinggi dengan nilai $\mathrm{IC}_{50}$ sebesar 16,51 $\mu \mathrm{g} / \mathrm{mL}$. Kombinasi ekstrak tersebut memiliki potensi antioksidan tertinggi dibandingkan perbandingan yang lain karena komponen polifenol seperti flavonoid berperan paling penting dengan aktivitas antioksidan dalam mencegah oksidasi lipid ${ }^{24}$.

Berdasarkan hasil nilai $I C_{50}$ menunjukkan bahwa kombinasi ekstrak etanol lidah buaya dan ganggang hijau 1:2 dan 2:1 memberikan efek aditif bila dikombinasikan, yang artinya penggunaan kedua ekstrak tersebut secara bersamaan dengan perbandingan 1:2 dan 2:1 memiliki pengaruh peningkatan aktivitas antioksidan dari salah satu atau kedua ekstrak yang dikombinasi. Kombinasi ekstrak etanol lidah buaya dan ganggang hijau 1:1 memberikan efek antagonis yang berarti memberikan efek penurunan terhadap aktivitas antioksidan dalam meredam radikal bebas DPPH. Pergaruh tersebut diduga terjadi akibat interaksi antara senyawa-senyawa kimia yang terdapat pada masing-masing ekstrak, secara teori pada tanaman selain zat aktif sebagai komponen utama yang paling penting berpengaruh 
Azizah Nada Septiawan, Emelda, Saddam Husein

Aktivitas Antioksidan Kombinasi Ekstrak Etanol Lidah Buaya (Aloe Vera L.) dan

Ganggang Hijau (Ulva Lactuca L.)

masih terdapat kandungan senyawa senyawa lainnya yang dapat mempengaruhi respon yang diharapkan ${ }^{20}$.

Kombinasi dari dua jenis ekstrak yang masing-masing mempunyai senyawa metabolit sekunder akan saling berinteraksi, dapat berefek potensiasi pada konsentrasi yang kecil dan juga sebaliknya yaitu saling melemahkan, selain itu perlu dipertimbangkan pada konsentrasi yang terlalu tinggi karena antioksidan berlebih akan berubah menjadi prooksidan atau menjadi toksik. Perlu diteliti lebih lanjut menggunakaan perangkat lunak CompuSyn untuk menentukan nilai Combination Index $(\mathrm{Cl})$ yang digunakan sebagai parameter interaksi antara kedua ekstrak, dimana data yang dimaksudkan adalah konsentrasi sebagai dosis dan absorbasi sebagai efek ${ }^{25}$.

Data persen inhibisi dianalisis menggunakan SPSS dengan uji normalitas data menggunakan uji Shapiro-Wilk dari hasil analisis terlihat bahwa kontrol positif, ekstrak tunggal lidah buaya dan ganggang hijau beserta kombinasinya nilai signifikansi $(p>0,05)$, yang artinya semua kelompok terdistribusi normal, karena data terdistribusi normal dilanjutkan dengan uji homogenitas menggunakan Test of Homogenity of Variances dapat disimpulkan bahwa data tidak homogen karena nilai signifikansi 0,022 $(p>0,05)$. Data yang digunakan terdistribusi normal dan tidak homogen, maka dilanjutkan dengan analisis one-way Anova. Berdasarkan uji ANOVA nilai signifikansi 0,209 $(p<0,05)$ yang artinya tidak terdapat perbedaan kelompok yang bermakna, selanjutnya dilakukan analisis post hoc Tamhane untuk mengetahui antar kelompok mana yang ada perbedaan ${ }^{26}$. Berdasarkan uji Tamhane disimpulkan bahwa tidak ada perbedaan yang bermakna pada kelompok karena $p<0,05$ tetapi yang paling terlihat pada kontrol positif dengan lidah buaya dengan nilai signifikan paling rendah.

\section{KESIMPULAN DAN SARAN}

Berdasarkan penelitian yang telah dilakukan dapat disimpulkan bahwa kombinasi ekstrak etanol lidah buaya (Aloe vera L.) dan ganggang hijau (Ulva lactuca L.) pada perbandingan 1:1, 1:2 dan 2:1 memiliki aktivitas antioksidan sangat dengan nilai $\mathrm{IC}_{50}$ masingmasing adalah $21,28 \mu \mathrm{g} / \mathrm{mL}$ dan $16,51 \mu \mathrm{g} / \mathrm{mL}$ dan 17,44 $\mu \mathrm{g} / \mathrm{mL}$. Kombinasi ekstrak etanol lidah buaya dan ganggang hijau 1:2 memiliki potensi antioksidan tertinggi dengan nilai IC $\mathrm{C}_{50}$ sebesar $16,51 \mu \mathrm{g} / \mathrm{ml}$.

Saran penelitian selanjutnya untuk melakukan pengukuran kadar fenol total pada ekstrak tunggal lidah buaya dan ganggang hijau dan ekstrak kombinas dan perlu dilakukan analisis efek farmakologis aktivitas antioksidan secara in vitro. 


\section{KONFLIK KEPENTINGAN}

Seluruh penulis menyatakan tidak terdapat potensi konflik kepentingan dengan penelitian dan atau publikasi artikel ini.

\section{DAFTAR PUSTAKA}

1. Winarsih H. Antioksidan Alami dan Radikal Bebas. Yogyakarta: Kanisius; 2007.

2. Aji RM. Uji Aktivitas Antioksidan pada Ekstrak Daging Daun Lidah Buaya (Aloe vera) menggunakan Metode DPPH. Fakultas IImu Kedokteran. 2014. p.26-8.

3. Joseph B, Raj SJ. Pharmacognostic And Phytochemical Properties of Aloe vera Linn - an Overview Taxonomy: Enzymes: October. 2010;4(2):106-10.

4. Emelda, Fatmawati A. Antioxidant Activity of Ethanolic Extract of Green Algae (Ulva lactuca Linn.) from Sepanjang Beach Gunung Kidul with DPPH Method. 2019.

5. Alagan VT, Valsala RN. Bioactive Chemical Constituent Analysis, in Vitro Antioxidant and Antimicrobial Activity of Whole Plant Methanol Extracts of Ulva lactuca Linn. 2017;15:1-14.

6. Yaich H, Garna H, Besbes S, Paquot M, Blecker C, Attia H. Chemical Composition and Functional Properties of Ulva lactuca Seaweed Pollected in Tunisia. Food Chemical [Internet]. 2011;128(4):895-901. Available from: http://dx.doi.org/10.1016/j.food chem.2011.03.114

7. Wicaksono IB, Ulfah M. Uji Aktivitas Antioksidan Kombinasi Ekstrak Etanol Daun Sirsak (Annona muricata L.) dan Daun Jambu Biji (Psidium guajava L.) dengan Metode DPPH (2,2-difenil-1-pikrihidrazil). Inovasi Teknik Kimia. 2017;2(1):44-8.

8. Marianne M, Patilaya P, Barus BT. Uji Aktivitas Antioksidan Kombinasi Ekstrak Etanol Rimpang Temu Giring (Curcuma Heyneana) dan Daun Pugun Tanoh (Curanga Fel-Terrae) menggunakan Metode Diphenyl Picrylhydrazil (DPPH). Talent Conference Series: Tropical Medicine. 2018;1(2):398-404.

9. Zainab, Choirunisa AH. Aktivitas Antioksidan Fraksi Etil Asetat dari Ekstrak Etanol $50 \%$ Daun Murbei Hitam (Morus nigra L.) dengan Metode DPPH serta Penetapan Kadar Fenol Total. Fakultas Farmasi Universitas Ahmad Dahlan, Yogyakarta. 2019;8:139-50.

10. Mahmud I, Pertiwi R, Azis NR, Reviana DN. Pemanfaatan Potensi Ganggang Hijau (Ulva lactuca) sebagai Antioksidan Alami pada Pencegahan Infark Miokard Akut. Fakultas Farmasi Universitas Ahmad Dahlan. 2014;1-7.

11. Emelda. Potensi Tongkat Ali (Eurycoma longifolia Jack.) sebagai Anti Inflamasi. Journal Current Pharmacy Sciences. 2017;1(1):25-9.

12. Latifah QA. Uji Efektifitas Ekstrak Kasar Senyawa Antibakteri pada Buah Belimbing Wuluh (Avverho belimbi) dengan Variasi Pelarut. [Skripsi]. Malang. UIN Malang. 2008.

13. Harborne J. Metode Fitokimia: Penuntun Cara Modern Menganalisis Tumbuhan. Bandung: Institut Teknologi Bandung; 1987.

14. Salamah N, Widyaningsih W, Izati I, Susanti H. Aktivitas Penangkap Radikal Bebas Ekstrak Etanol Ganggang Hijau Spirogyra sp. dan Ulva lactuca dengan Metode DPPH. Jurnal Ilmu Kefarmasian Indonesia. 2015;13(2):145-50.

15. Sayuti K, Yenrina R. Antioksidan Alami dan Sintetik. Padang : Andalas University Press; 2015. 76-78.

16. Arifin R, Bangsawan PI, Andriani. Efek Hepatoprotektor Ekstrak Etanol Lidah Buaya (Aloe vera) Terhadap Aktivitas Enzim Alanin Aminotransferase (ALT) dalam Plasma Rattus norvegicus Jantan Galur Wistar yang diinduksi Parasetamol. Fakultas Kedokteran Universitas Tanjungpura. 2014;9-10. 
17. Fatimah I, Hidayat $\mathrm{H}$, Nugroho BH, Husein $\mathrm{S}$. Ultrasound-assisted biosynthesis of silver and gold nanoparticles using Clitoria ternatea flower. South African Journal of Chemical Enginnering. 2020;34:97-106.

18. Riyanto, Wirayah C. Stabilitas Sifat Antioksidatif Lidah Buaya (Aloe vera Var. Chinensis) selama Pengolahan Minuman Lidah Buaya. 2012;32(1):73-8.

19. Suhalang S. Uji Aktivitas Antioksidan Ekstrak Metanol Kacang Merah (Phaseolus vulgaris L.) dengan Metode DPPH. [Skripsi]. Makassar: Universitas Islam Negeri Alauddin Makassar.2010.

20. Hidayat M. Aktivitas Ekstrak Protein Biji Kedelai (Glycine Max L. Merr) Varietes Detam 1 terhadap Pengendalian Berat Badan dan Peningkatan Kadar Kolesistokinin Melalui Mekanisme Aktivitas Mitogen Activated Protein Kinase (MAPK) pada Tikus Wistar Jantan. Universitas Padjadjaran. 2011.

21. Huliselan Y, Defny SW. Aktivitas Antioksidan Ekstrak Etanol, Etil Asetat dan n-Heksandari Daun Sesewanua (Clerodendron Squamatum Vahl.). Pharmacon Jurnal Ilmiah Farmasi. 2015;4(3):155-63.

22. Mahadi SB, Handayani RAS, Widowati W, Wilsen W, Dewani Y, Fachrial E, et al. Antioxidant and Anti-Tyrosinase Activities of Aloe vera Rind and Gel Extracts. Global Medical Health Communication. 2020;7(3):170-6.

23. Shoviyyah. Uji Aktivitas Antioksidan dan Fitokimia Fraksi Etil Asetat, Kloroform, dan Metanol Ekstrak Alga Hijau Ulva lactuca dari Pantai Gunung Kidul Yogyakarta. [Skripsi]. Malang:Universitas Islam Negeri Maulana Malik Ibrahim 2019.

24. Sannigrahi S, Upal K., Dilip K., Sambit P, Sourabh J. Antioxidant Potensial of Crude Extract and Different Fractions of Enhyra fluctuans Lour. Iranian Journal of Pharmaceutical Research. 2010;9(1):75-82.

25. Chou TC. Theoretical basis, experimental design, and computerized simulation of sinergism and antagonism in drug combination studies. PharmacolRev. 2006;58(3):62181.

26. Dahlan S. Statistik Untuk Kedokteran Dan Kesehatan Edisi 6. Jakarta: Salemba Medika; 2014. 110-116 p. 